\title{
Comparative Effects of Organic and Inorganic Priming on Seed Quality Parameters of Fenugreek (Trigonella foenumgraecum $\mathrm{L}$.)
}

\author{
Kalneni Jahnavi $^{1 *}$, G. Abdul Wajid ${ }^{1}$, Arun Kumar Chaurasia ${ }^{1}$, \\ B. Prudvi Raj Naidu ${ }^{2}$ and N. Bharath Reddy ${ }^{2}$
}

${ }^{1}$ Department of Genetics and Plant Breeding, Naini Agricultural Institute, Sam Higginbottom University of Agriculture, Technology and Sciences, Prayagraj, 211007 U. P., India

${ }^{2}$ State Institute for Management of Agriculture, Department of Agriculture, Govt of. Uttar Pradesh, India

*Corresponding author

\section{A B S T R A C T}

Keywords

Fenugreek, GA3, PEG 6000, $\mathrm{KNO}_{3}$, $\mathrm{CaCl}_{2}$, Aloe Vera exract, Curry leaf extract,

Gingerextract,

Moringa leaf extract, Tulasi leaf extract, Priming, Germination, CRD

Article Info

\section{Accepted:}

04 November 2020

Available Online:

10 December 2020

\begin{abstract}
Fenugreek is one of the major and important spices grown in India. Application of commercial antioxidants and nutrients for seed enhancement is expensive and not easily accessible by the farmers. The hereby study was conducted in a completely randomized design with four replications in controlled conditions at Department of Genetics and Plant Breeding, SHUATS, Prayagraj (U.P) during 2018-2020, to assess the potential of botanicals for germination, seedling vigour and germination index in fenugreek. Inorganic and organic priming methods were adopted and treatments used are as $\mathrm{T}_{0}$ (Control), $\mathrm{T}_{1^{-}}$Distilled water, $\mathrm{T}_{2}-\mathrm{KNO}_{3}(1 \%), \mathrm{T}_{3^{-}}\left(\mathrm{KNO}_{3}(3 \%), \mathrm{T}_{4^{-}} \mathrm{GA} 3\right.$ (100ppm), $\mathrm{T}_{5}$-PEG (20\%), $\mathrm{T}_{6^{-}} \mathrm{CaCl}_{2}(1 \%),, \mathrm{T}_{7^{-}} \mathrm{CaCl}_{2}(3 \%), \mathrm{T}_{8^{-}}$Aloevera leaf extract $(5 \%), \mathrm{T}_{9^{-}}$Moringa leaf extract (5\%), $\mathrm{T}_{10^{-}}$Curry leaf extract $(5 \%), \mathrm{T}_{11^{-}}$Tulasi leaf extract $(5 \%) \& \mathrm{~T}_{12}$-Ginger extract $(5 \%)$. It was found that all the treatments showed significant effect on quality parameters. The highest germination percentage (\%), speed of germination, seedling length $(\mathrm{cm})$, seedling fresh weight $(\mathrm{g})$, seedling dry weight $(\mathrm{g})$, and vigour indices were observed in treatment $\mathrm{T}_{12}$-Ginger extract (5\%) priming for 12 hours. This study revealed that organic priming with botanicals can be effective in enhancing seed quality parameters in fenugreek, and are cost effective, economical, non-toxic and nature-friendly.
\end{abstract}

\section{Introduction}

India, the land of spices is the world's largest producer, consumer and exporter of wide range of spices, more than 60 spices are cultivated in India. The country produces more than two million tons of spices annually. Fenugreek (Trigonella foenumgraecum L.) commonly known as methi is an annual forage crop and a traditional spice and aromatic crop that has been grown for centuries. It is diploid $(2 \mathrm{n}=16)$, belongs to the family leguminaceae and it is believed to be native to the Mediterranean region, but now it is widely cultivated in India and other parts of the world. It is a multipurpose crop grown 
during winter season for seed, vegetable and condiment purposes in various parts of the country. Fenugreek is widely used as fodder crop because of its ability to provide high quality forage at all stages of growth. Fenugreek is mainly cultivated for its seeds, which are used as spice (Acharya et al., 2008) or dye.

Fenugreek is an annual quick growing herb, up to $30-90 \mathrm{~cm}$ in height with light to dark green trifoliate leaves with or without pink margins. It produces small white coloured flowers at base of each leaf. The flowers are hermaphrodite, papilionacious, in which fertilization occurs in unopened flowers. It is mainly grown in rabi season. It is native of South Eastern Europe and West Asia.

India is the largest producer and exporter in the world. It is cultivated across the country though production is concentrated in Madhya Pradesh, Rajasthan, Gujarat. In India it is cultivated in an area of 149330 ha with 213340 tons production. In India, Madhya Pradesh ranks top in Fenugreek production the state wise production includes, Madhya Pradesh (95850t), Rajasthan (81150t), Gujarat (13530t), Haryana (7470t), West Bengal (2750t), Uttaranchal (2610t). (Source: Spice Board of India-2017-18).

The medicinal properties of fenugreek were recorded by the Egyptians and Hippocrates (Lust, 1974), making it one of the oldest recoded plants used in medicine (Acharya et al., 2008). The seeds have the good therapeutic properties (Fazil and Hardman, 1967), against digestive disorders (Sharma et al., 1991), diabetes (Jain et al., 1987)and diuretic actions too (Tanira et al., 1989). The seeds compose ample amounts of soluble dietary fiber. Soaking them in water softens their outer coat and turns it slimy (mucilaginous). Carminative, tonic, aphrodisiac, emollient, anti-bacterial, used for nausea, fever, anorexia and colonitics. (Source: Spice Board of India)

Fenugreek has high nutrition values. $100 \mathrm{~g}$ of seeds provide am $24.6 \mathrm{~g}$ or over $65 \%$ of dietary fiber. Nutritional value for $100 \mathrm{~g}$. includes energy-323Kcal, carbohydrates $58.35 \mathrm{~g}$, protein- $23.00 \mathrm{~g}$, total fat- $6.41 \mathrm{~g}$, dietary fiber- $24.6 \mathrm{~g}$, cholesterol $0 \mathrm{mg}$ (USDA National Nutrient data base)

Seed is a biological entity and deterioration after harvest is inevitable. In spices seed quality may be deteriorated due to fluctuating temperatures and humidity during storage, various diseases (Meena et al., 2013). These effected seeds show poor germination and low vigor. Quality seed is the pre requisite for any crop improvement program. It ensures good germination, rapid emergence, vigorous growth and increased yields. Quality seeds have the ability to use the inputs such as irrigation, fertilizers, and nutrients efficiently (Mirza Hasanuzzaman (2015). Seed quality can be maintained either by storing seed in controlled condition or by seed treatments.

Seed enhancements aim to improve seed germination and seedling growth, encompasses many techniques performed on seed after harvest and before sowing (Copeland and McDonald, 1995 and Taylor et al., 1998). A simple, low-cost, low-risk technology called 'on farm seed priming has been shown to improve emergence, seedling vigor and yield in a range of crops, including legumes (Harris et al., 1999; Musa et al2001 and Kumar et al., 2002). Seed priming is one of the invigoration treatment that involves controlled hydration of seed to a level that permits pre-germinative metabolic activity to proceed, but that prevents actual emergence of the radical (Vanangamudi et al., 2010). Priming of seeds has shown to have beneficial effects on the germination and emergence of many species (Bradford, 1986). The direct 
benefits of seed priming in crops include faster emergence, improved germination, uniformity, vigorous plants and higher yields. The indirect benefits are earlier sowing and harvest and decreased risk of crop failure (Harris et al., 2001)

\section{Materials and Methods}

The Research study was conducted at Seed Testing Laboratory, Department of Genetics and Plant Breeding, Naini Agriculture Institute, Sam Higginbottom University of Agriculture, Technology and Sciences, Prayagraj during rabi-2019 to find out "Comparative effects of organic and inorganic priming on seed quality parameters of fenugreek (Trigonella foenumgraecum L.)". The data was collected on ten randomly selected healthy seedlings plants from each replication and different observations were recorded.

The treatments were represented as $\mathrm{T}_{0}$ (Control), $\mathrm{T}_{1}$ - Distilled water, $\mathrm{T}_{2}-\mathrm{KNO}_{3}(1 \%)$, $\mathrm{T}_{3}-\mathrm{KNO}_{3}(3 \%), \mathrm{T}_{4^{-}} \mathrm{GA} 3(100 \mathrm{ppm}), \mathrm{T}_{5^{-}} \mathrm{PEG}$ 6000 (20\%), $\mathrm{T}_{6}-\mathrm{CaCl}_{2},(1 \%),, \mathrm{T}_{7}-\mathrm{CaCl}_{2}$, (3\%), and $\mathrm{T}_{8^{-}}$Aloevera leaf extract $(5 \%), \mathrm{T}_{9^{-}}$ Moringa leaf extract (5\%), $\mathrm{T}_{10^{-}}$Curry leaf extract $(5 \%), \mathrm{T}_{11}$ - Tulasi leaf extract $(5 \%) \&$ $\mathrm{T}_{12}$-Ginger extract (5\%).

\section{Preparation of solutions}

The solution of $\mathrm{KNO}_{3} \quad(1 \% \& 3 \%)$ was prepared by dissolving $1 \mathrm{gm} \& 3 \mathrm{gm}$ of $\mathrm{KNO}_{3}$ in $100 \mathrm{ml}$ of distilled water each in separate beakers. The solution of $\mathrm{CaCl}_{2}(1 \%$ \& 3\%) was prepared by dissolving $1 \mathrm{gm} \& 3 \mathrm{gm}$ of $\mathrm{CaCl}_{2}$ in $100 \mathrm{ml}$ of distilled water each in separate beakers.

For the preparation of GA3 (100ppm), 100mg of GA3 is dissolved in $1000 \mathrm{ml}$ of distilled water. For the preparation of botanical leaf extracts Moringa, Curry leaf, Tulasi leaves were collected from Horticulture Research fields, SHUATS.

These leaves were shade dried and made into fine powder. $5 \mathrm{~g}$ of each powder is dissolved in $100 \mathrm{ml}$ of distilled water to make $5 \%$ solution. Ginger extract is prepared by grinding $5 \mathrm{~g}$ of fresh ginger with $100 \mathrm{ml}$ of distilled water. Aloe vera leaf extract is prepared by grinding $5 \mathrm{~g}$ of aloe vera with $100 \mathrm{ml}$ of distilled water.

After preparation of solutions, seeds were soaked in for a duration of $12 \mathrm{hr}$ and shade dried.

These seeds were used for further laboratory studies to record observations.

\section{Results and Discussion}

It is evident from the present investigation that priming treatments has significant effect on quality parameters in fenugreek. In general, most of the treatments have increased germination and vigour parameters as compared to control (untreated seeds).

Germination percent (90.75\%), speed of germination (213.11) were highest in seeds treated with $\mathrm{T}_{12}$-Ginger extract (5\%). Seedling parameters such as root length $(7.67 \mathrm{~cm})$, shoot length $(14.46 \mathrm{~cm})$, seedling length $(22.13 \mathrm{~cm})$, seedling fresh weight $(2.37 \mathrm{~g})$, seedling dry weight $(0.11 \mathrm{~g})$, vigor index-I (2009.2) and vigor index-II (12.66) were recorded highest in seeds treated with $\mathrm{T}_{12}$-Ginger extract $(5 \%)$ followed by $\mathrm{T}_{11}$ Tulasi leaf extract $(5 \%)$ however, $\mathrm{T}_{0}$-Control being the lowest.

Similar results were observed by Hasan et al., (2005), Misrak Kebede et al., (2015), Dileepkumar Masuthi et al., (2015), Cupcupin et al., Vinothni and Bhavyasree (2019) (Table 1). 
Table.1 Mean performance of seed quality parameters due to various priming treatments in fenugreek

\begin{tabular}{|c|c|c|c|c|c|c|c|c|c|c|}
\hline S.no & Treatments & $\begin{array}{c}\text { Germination } \\
\text { percentage }\end{array}$ & $\begin{array}{c}\text { Speed of } \\
\text { germination }\end{array}$ & $\begin{array}{c}\text { Root } \\
\text { length }\end{array}$ & $\begin{array}{c}\text { Shoot } \\
\text { length }\end{array}$ & $\begin{array}{c}\text { Seedling } \\
\text { length }\end{array}$ & $\begin{array}{c}\text { Seedling } \\
\text { fresh } \\
\text { weight }\end{array}$ & $\begin{array}{c}\text { Seedling } \\
\text { Dry } \\
\text { weight }\end{array}$ & $\begin{array}{c}\text { Seedling } \\
\text { Vigour } \\
\text { Index-I }\end{array}$ & $\begin{array}{c}\text { Seedling } \\
\text { vigour } \\
\text { Index-II }\end{array}$ \\
\hline $\mathbf{1}$ & & & & & & & & & & \\
$\mathbf{T}_{\mathbf{0}}$ & 71.750 & 107.513 & 5.125 & 10.975 & 16.100 & 1.500 & 0.060 & $1,154.725$ & 4.298 \\
\hline $\mathbf{2}$ & $\mathbf{T}_{\mathbf{1}}$ & 81.250 & 139.488 & 6.650 & 13.025 & 19.675 & 2.125 & 0.070 & $1,598.900$ & 5.688 \\
\hline $\mathbf{3}$ & $\mathbf{T}_{\mathbf{2}}$ & 78.000 & 118.998 & 5.750 & 13.878 & 19.628 & 1.600 & 0.064 & $1,531.020$ & 4.970 \\
\hline $\mathbf{4}$ & $\mathbf{T}_{\mathbf{3}}$ & 82.750 & 136.940 & 6.625 & 11.660 & 18.285 & 2.050 & 0.075 & $1,513.255$ & 6.205 \\
\hline $\mathbf{5}$ & $\mathbf{T}_{\mathbf{4}}$ & 87.750 & 143.700 & 7.400 & 14.200 & 21.600 & 2.263 & 0.105 & $1,895.450$ & 9.178 \\
\hline $\mathbf{6}$ & $\mathbf{T}_{\mathbf{5}}$ & 79.750 & 164.420 & 5.750 & 12.113 & 17.863 & 1.950 & 0.075 & $1,424.675$ & 5.975 \\
\hline $\mathbf{7}$ & $\mathbf{T}_{\mathbf{6}}$ & 82.500 & 115.238 & 5.675 & 13.638 & 19.313 & 1.550 & 0.063 & $1,594.142$ & 5.158 \\
\hline $\mathbf{8}$ & $\mathbf{T}_{\mathbf{7}}$ & 88.500 & 178.793 & 7.050 & 14.085 & 21.135 & 2.250 & 0.103 & $1,870.685$ & 9.065 \\
\hline $\mathbf{9}$ & $\mathbf{T}_{\mathbf{8}}$ & 82.250 & 176.263 & 5.450 & 12.778 & 18.228 & 1.738 & 0.060 & $1,498.792$ & 4.930 \\
\hline $\mathbf{1 0}$ & $\mathbf{T}_{\mathbf{9}}$ & 84.500 & 178.793 & 6.325 & 14.070 & 20.395 & 2.050 & 0.073 & $1,722.705$ & 6.135 \\
\hline $\mathbf{1 1}$ & $\mathbf{T}_{\mathbf{1 0}}$ & 75.000 & 121.670 & 6.675 & 12.925 & 19.600 & 2.125 & 0.085 & $1,471.050$ & 6.375 \\
\hline $\mathbf{1 2}$ & $\mathbf{T}_{\mathbf{1 1}}$ & 89.250 & 180.745 & 7.425 & 14.263 & 21.688 & 2.375 & 0.113 & $1,935.575$ & 10.010 \\
\hline $\mathbf{1 3}$ & $\mathbf{T}_{\mathbf{1 2}}$ & $\mathbf{9 0 . 7 5 0}$ & $\mathbf{2 1 3 . 1 1 5}$ & $\mathbf{7 . 6 7 5}$ & $\mathbf{1 4 . 4 6 3}$ & $\mathbf{2 2 . 1 3 8}$ & $\mathbf{2 . 5 5 0}$ & $\mathbf{0 . 1 4 0}$ & $\mathbf{2 , 0 0 9 . 0 2 5}$ & $\mathbf{1 2 . 6 6 8}$ \\
\hline Grand $\mathbf{m e a n}$ & 82.61 & 145.55 & 6.42 & 13.23 & 19.66 & 2.009 & 0.083 & 1632.32 & 6.97 \\
\hline & $\mathbf{C . D .}$ & 2.264 & 15.048 & 0.314 & 0.602 & 0.743 & 0.134 & 0.018 & 81.172 & 1.565 \\
\hline & $\mathbf{S E}(\mathbf{m})$ & 0.789 & 5.241 & 0.109 & 0.210 & 0.259 & 0.047 & 0.006 & 28.270 & 0.545 \\
\hline & $\mathbf{S E}(\mathbf{d})$ & 1.115 & 7.412 & 0.155 & 0.296 & 0.366 & 0.066 & 0.009 & 39.980 & 0.771 \\
\hline & $\mathbf{C . V}$ & 1.909 & 7.201 & 3.399 & 3.167 & 2.633 & 4.655 & 14.840 & 3.464 & 15.628 \\
\hline
\end{tabular}

From the present investigation it is concluded that the pre-sowing treatments with organic priming can be used for enhancement of germination and vigor of fenugreek. Organic priming with $\mathrm{T}_{12}$ (Ginger extract @ 5\%) was found to be best in all the treatments followed by $\mathrm{T}_{11}$ (Tulasi extract @ 5\%), T4 (GA3@ 100ppm) and $\mathrm{T}_{7}\left(\mathrm{CaCl}_{2} @ 3 \%\right)$ and control being the lowest. The experimental observations of increase in germination and quality parameters indicate the effect of botanicals on physiological processes of the seeds. Botanicals being cheap, nature friendly and easily available to farmers can be efficiently used for improving seed quality parameters.

\section{References}

Çavuşoğlu, D., Tabur, S., and Çavuşoğlu, K. (2016). The effects of Aloe vera L. leaf extract on some physiological and cytogenetical parameters in Allium cepa L. seeds germinated under salt stress. Cytologia, 81(1), 103-110.

Cupcupin, J. P., and Samson, M. R. P. The Effects of Agua oxinada and GarGin Crude Extract in the Germination of Tomato (Solanum lycopersicum) Seeds.

Hasan, M. M., Chowdhury, S. P., Alam, S., Hossain, B., and Alam, M. S. (2005). Antifungal effects of plant extracts on seed-borne fungi of wheat seed regarding seed germination, seedling health and vigour index. Pak. J. Biol. Sci, 8(9), 1284-1289.

Jagtap, D. (2012). Physiological response of fenugreek (Trigonellafoenum-graecum L.) during germination under the influence of Gibberellic acid and Oxygenated peptone. Bionano Frontier, 5, 86-88.

Kebede, M., Ayalew, A., \&Yesuf, M. (2013). Efficacy of plant extracts, traditional materials and antibacterial chemicals 
against Xanthomonas campestris pv. vesicatoria on tomato seed. African Journal of Microbiology Research, 7(20), 2395-2400.

Langeroodi, A. R. S., and Noora, R. (2017). Seed priming improves the germination and field performance of soybean under drought stress. The Journal of Animal and Plant Sciences, 27(5), 1611-1621.

Masuthi, D., Chavan, M. L., Khaja Rubina, S., Ramangouda, S. H., Abdul Kareen, M., Prabhakar, I. and Haleshkumar, B. (2015). Different priming treatments on germination and viability of cluster bean seeds. International Journal of Advanced Research, 3(5), 108-111.

Moradi, A., and Younesi, O. (2009). Effects of osmo-and hydro-priming on seed parameters of grain sorghum (Sorghum bicolor L.). Australian Journal of Basic and Applied Sciences, 3(3), 1696-1700.

Patil, K., Ravat Anilkumar, L., Trivedi, V., Hirpara, A., and Sasidharan, N. (2018).
Effect of seed priming treatment in chickpea (Cicer arietinum L.). IJCS, 6(4), 1064-1069.

Saini, R., Rai, P. K., Bara, B. M., Sahu, P., Anjer, T., and Kumar, R. (2017). Effect of different seed priming treatments and its duration on seedling characters of Bitter gourd (Momordica charantia L.). Journal of Pharmacognosy and Phytochemistry, 6(5), 848-850.

Singh, S., Lal, G. M., Bara, B. M., and Mishra, S. N. (2017). Effect of hydropriming and osmopriming on seed vigour and germination of Pea (Pisum sativum L.) seeds. J. Pharmacognosy and Phytochemistry, 6(3), $820-824$.

Soughir, M., Aymen, E. M., and Cherif, H. (2012). Effect of $\mathrm{NaCl}$ priming duration and concentration on germination behavior of fenugreek. Albanian Journal of Agricultural Sciences, 11(4), 193.

\section{How to cite this article:}

Kalneni Jahnavi, G. Abdul Wajid, Arun Kumar Chaurasia, B. Prudvi Raj Naidu and Bharath Reddy, N. 2020. Comparative Effects of Organic and Inorganic Priming on Seed Quality Parameters of Fenugreek (Trigonella foenumgraecum L.). Int.J.Curr.Microbiol.App.Sci. 9(12): 150-154. doi: https://doi.org/10.20546/ijcmas.2020.912.020 